\title{
Optical education for application in science and industry at a technical university: combination of laser physics and technology, electronics engineering and computer sciences
}

Sergei Arakelian, Vitalii Orlov, Valerii Prokoshev, L. Sushkova

Sergei M. Arakelian, Vitalii N. Orlov, Valerii G. Prokoshev, L. T. Sushkova, "Optical education for application in science and industry at a technical university: combination of laser physics and technology, electronics engineering and computer sciences," Proc. SPIE 2525, 1995 International Conference on Education in Optics, (13 October 1995); doi: $10.1117 / 12.224027$

Event: SPIE's 1995 International Symposium on Optical Science, Engineering, and Instrumentation, 1995, San Diego, CA, United States 


\title{
OPTICAL EDUCATION FOR APPLICATION IN SCIENCE AND INDUSTRY AT A TECHNICAL UNIVERSITY :COMBINATION OF LASER PHYSICS AND TECHNOLOGY, ELECTRONICS ENGINEERING AND COMPUTER SCIENCES
}

\author{
S.M.Arakelian ,V.N.Orlov,V.G.Prokoshev,L.T.Sushkova \\ Vladimir State Technical University \\ Gorkii str. 87, Vladimir, Russia \\ tel.(09222)79621, fax (09222)33358, e-mail:wlad\%rtf@vpti.vladimir.su
}

\begin{abstract}
The main aspects of our approach are enumerated as follow:

- the importance of the fundamental training in the field of laser sciences and optical education, all-round training;

- flexibility and individuality of training, the optimum correlation between the curricula of various specialties;

- the openness of training system and the possibility for students to obtain additional knowledge in different leading national centers;

- calling for the profession, social protection and guarantee from unpredictable situations and from the demand for marketing of professions.
\end{abstract}

Keywords: optical education, interdisciplinary studies, laser sciences, laser technology, computers, laser in medicine, optoelectronics.

1. INTRODUCTION

The uniqueness of our experience is based upon the integrated approach in the preparation of specialists in the field of laser sciences and technologies, the main point of which is forming the academic groups on the basis of electro-(radio) engineering, mechanics and technology and computer education, gained during the first three years of studies in the following specialties: "Radio engineering", "Design and technology of radio electronic devices", "Computers, complexes, systems, networks", "Technology of Mechanical Engineering", "Automation of Technological Processes and Production".

Further laser orientation of students takes place at the 4-5 years in one out of three specializations: "Laser physics and optoelectronics", "Lasers in medicine", "Computers and mathematical modeling". Training is being given in parallel with the basic one.

For realization of such a plan of the specialists preparation, the curricula of above mentioned specialties and specializations have been coordinated in a single module. This approach enables to find the optimum correlation between fundamental and special education at a Technical University in laser
sciences.

Directly at the University on the basis of the Physics and Applied mathematics department there have been organized modern lab workshops on lasers and optoelectronics, on computer systems and on laser medical equipment. Accent is made on the newest systems, often unique, received on the terms of the agreements on cooperation with the leading national companies and research military-industrial laboratories, working in this area in Vladimir region (DB "Raduga", SC "Vector", PC "Technica", PC "Electropribor", Regional Cardio Center and others).

The leading specialists of these companies are drawn into delivering lectures at the University. It's common to invite visiting professors from the Lomonosov Moscow State University (MSU) and institutes of the Russian Academy of Sciences (RAS) and other National leading centers as well as from foreign countries for reading lectures to the students (short intensive courses).

The students are directed to these institutions on the practical academic work and pre diploma practices, short courses as well as for fulfilling diploma projects. The last one includes carrying out self-sufficient searching assignment. 
The organization of the integrated preparation of specialists in this area is associated with the setting up at Vladimir State Technical University (VSTU) a branch of the International Laser Center of MSU (accent is made on academic and scientific activities) and the Regional Laser Engineering Center (manufacturing education as a basis). The latter carries out its work in close contacts with the Research Center on Technological Lasers of the RAS (the town of Shatura). The Regional Research-Practical Laboratory on the Laser Medicine is established as well on the basis of the clinics and hospitals of Vladimir region and on the basis of VSTU.

The main aspects of discussed approach:

- the importance of the fundamental training in the field of laser sciences and optical education, all-round training;

- flexibility and individuality of training, the optimum correlation between the curricula of various specialties;

- the openness of training system and the possibility for students to obtain additional knowledge in different leading national centers;

- calling for the profession, social protection and guarantee from unpredictable situations and from the demand for marketing of professions.

Further development and perspectives of the given training system are associated with the realization of total enrollment of applicants into common specialty (e.g. Applied Mathematics and Physics) within a single Faculty of Radio physical orientation, and/or the Technology of Mechanical Engineering Division, and/or the Applied Mathematics and Physics Department, and/or Natural Sciences Department, with the following specialization of students in the narrower field, beginning from the third year of studies. It's common practice for classical university education, as it contributes to raising the effectiveness of education, provides its flexibility. Moreover the system helps the students to make a reasonable choice of the future profession.

The possibility of student's participation in academic and manufacturing areas in terms of various State funding Federal scientific programs contributes to developing of independent and global thinking in the field of high-tech, in particular of laser technologies. After finishing the University they can see the perspectives of development of science and technology, and by such a knowledge could work independently both in $R \& D$ area and in industry including the small business industrial enterprises.

\section{CLASSIFICATION OF THE SPECIALTIES COMPOSING THE MODULE OF LASER SCIENCES AND TECHNOLOGY EDUCATION}

\subsection{The new specialty "Applied Mathematics (and Physics )"}

The specialty was established in March, 1994 by Act of the Ministry of Higher Education of Russia and is now a unique one of the natural science profile at the Vladimir State Technical University.

On September 1, 1994 the instructions on the specialty are presently offered by the University for the first time, and the students can specialize on the bachelor's, master's and doctoral degrees in three areas listed below :

- computer science and mathematical modeling;

- laser physics and optoelectronics;

- lasers in medicine.

These areas appear to be in constantly increasing demand. The objective of the study on this program is to provide intensive preparation in the design, programming, theory and applications of computers and/or lasers (optoelectronics ). Training is provided for both academically oriented students and students with professional goals in the many business, industrial or governmental occupation requiring advanced knowledge of computer and/or laser (optoelectronics) theory and technology. The purpose of the program in this field is also the development of general as well as of specific skills for management decision analysis in economics and business to solve the complex problems of future managers on the basis of nonlinear physics including the modern models of nonlinear open systems with feedback.

The research effort in Laser Physics is devoted mainly to the development of new types of lasers from the infra-red and visible to the gamma-ray spectrum, of laser-technology, of nonlinear-optical effects and spectroscopy, of diagnostics, of coherent pulse propagation, of laser-induced processes in 
condensed matter and gas, of quantum optics etc. The Optoelectronics emphasizes use of semiconductor lasers and of computers in experimental data acquisition and computer control in the different processes. Areas of interest include data collection, experimental interfacing, laboratory and/or technologyoriented computer hardware, optical data acquisition operating systems and data analysis, neural computing and networks.

The objective of the study on Laser in Medicine is to provide basic and clinical studies on the therapeutic and diagnostic use of lasers in all of the surgical and medical specialties, e.g. clinical trials, new therapeutic techniques or instruments, laser biophysics and bioengineering, photo biology and photo chemistry. The current service of the laser medical equipment in a real practice is also a goal of such an approach.

Courses and research are offered in a variety of subfields of Computer Science, Laser Physics, Optoelectronics and Medicine, including:

- computer graphics, pattern recognition, automata theory, combinatorics, artificial intelligence,

database design, optical fiber memory, fuzzy logic and neural networks;

- marketing management, managerial economics and analysis;

- numerical methods in physics, physics of lasers, nonlinear and quantum optics, research in quantum electronics, fiber optics, laser technology, high power lasers and laser applications, nonlinear wave processes, stochasticity and open systems;

- quantitative biology, biomedical laser maintenance and operation, laser medical applications and laser safety, biophysics and medical physics, ecological sciences and air/space diagnostics.

Key words: computer, laser, optoelectronics, communication, data processing, economics, ecology, super high sensitive diagnostics, medicine and ... absolutely brilliant people!

Computers and lasers are being applied to a wide range of problems, both fundamental and applied, give a double effect of efficiency and gain in high technologies. The future is there for this development. So, a such an excited field, i.e. the Applied Mathematics (and Physics) is a very popular direction among the students at a Technical University.

\subsection{Specialty "Computer Systems. Complex \& Networks"}

Department of Computer Science (CS) prepares a qualified specialists in this prestigious field.

In many departments/faculties a fair idea of computers is given, however for them, computer is the main media to achieve better perspectives. Department of CS is the only one in Vladimir State Technical University which prepares students in a major of CS (software and hardware).

The students who graduate from this department are specialists in the field of modern computer systems. They know the principles of designing, architecture and methods of complex analysis. They also can use the new technology and software, design systems of every level.

During the education period, students achieve a maximum knowledge in programming languages, work with software packages and hardware technology.

Department provides the well equipped laboratories, latest computers and special devices. This specialization guaranties the good chance to get a job.

\subsection{Specialty "Design and Technology of Radio-Electronic Devices"}

Department of Design and Technology of Radio-Electronic Devices was founded as part of the RadioEngineering faculty in 1972.

Radio-Electronic Equipment Design \& Technology Department can offer to students the specialty similar to the following technical sciences like computer science, electrical engineering, industrial engineering \& etc.

For example, at the department the students can get following skills and knowledge:

- computer-aided design and computer-aided manufacturing of complex radio-electronic devices on various computers

- design \& manufacturing of large-scale integral circuits, including microprocessors

- design \& manufacturing of various radio-electronic devices like: TV sets, telecasting stations,

audio- and video-tape recorders, computers, kitchen-laundry combines, TV game computers, etc. 


\author{
- design of complex radio-electronic devices using in atomic stations, in space, etc \\ Department offers the following courses: \\ Engineering Drawing \\ Computer Programming \\ Theoretical Mechanics \\ The Physico-Chemical Fundamentals of Microelectronics Devices \\ Electronics \\ Standardization, Measurement and Control of Quality \\ Materials and Technology of Radio-Electronics Devices Parts \\ Engineering Creation \\ Functional Electronics Devices and Radio-Electronics Parts \\ Radio technical Systems \\ Automatic Design and Technology of Radio-Electronic Devices \\ Design and Technology of Microprocessors \\ Fundamentals of Design, Technology and Reliability \\ Technical Electrodynamics \\ Mechanical Effects and Protection of Radio-Electronic Devices \\ Heat and Mass Exchange in Radio-Electronic Devices \\ Computer-Aided Design of Radio-Electronic Devices \\ Organizing, Planning and control of Enterprises \\ Microprocessors and Microcomputers application in Radio-Electronic Devices \\ Design of Radio-Electronic devices \\ Technology of Radio-Electronic devices and Automatic Production \\ Design of Radio-Electronic Mechanisms \\ Software of Systems for Automatic Design \\ Methods and Means for Tests of Radio-Electronic Devices \\ Radio technical Circuits and Signals \\ Analog and Digital Electronics \\ Technology Training \\ Computer Graphics
}

Department offers the following specializations for graduate students:

Solid-State Electronics

Integral Radio-Electronic Devices

Communication Devices

\title{
2.4. Specialty "Automation of Technological Processes and Production"
}

The principal directions of the department's scientific research are connected with new discoveries of automated systems using intense scientific processes. Paramount is the creation of roboto-technical devices and mechanisms for the automation of industrial processes in the fields of business, agriculture and automotive diagnostics.

The department is currently preparing electrical engineers in specialty "Automation of Technical Processes and Production."

Automation is a means of increasing the efficiency of human thought processes in the sphere of supervision. Therefore, it is useful in such stages of production as performing difficult calculations in construction projects, modeling and finding new answers, database processing, computerized design, performing technical and termination of operational codes, and the solving of operational algorithms.

Automation today is not only the production processes, but computerization of bank operations and accounting with the latest electronic devices, mathematical programs and software.

Since 1995, new educational programs have been used to prepare specialists. Specialists are prepared to work as electrical engineers who design and build automated systems for large and small 
businesses, as well as small factories which convert raw material into finished products in various fields of industry.

During their studies, students gain a deep knowledge of computers, programming, algorithmic languages, and specific control systems for various production processes.

The profile of electrical engineers is formed by the study of the courses: "Counting Technique", "Control of Microprocessor Systems", "Informational Units of Systems Management", "Methods and Devices for the Measurement of Physical Quantities", "Electronic and Semiconductor Technology", and others.

Graduates work in private firms, banks, departments of administrative management, and departments of manufacturing enterprises. Many graduates work in firms as directors, managers, and supervisors in management, automation, marketing, energy, and private enterprises.

\subsection{Specialty "Technology of Mechanical Engineering"}

The Department of Mechanical Engineering Technology was organized in 1966. Since that time it trains specialists for machine-building branches of industry. Graduates work all around the world. Many of them have become heads of enterprises, shop superintendents, department heads and specialists in research and design. Organizing small businesses, joint ventures, firms and commercial structures they successfully apply the knowledge and skills they have received from the university.

In 1994, "Technology and Management of Convenient Goods" was opened as a new branch within this specialty. In the conditions of the market economy, preparation of specialists for production of convenience items is in current demand. Graduates of this specialty, in addition to the general preparation which engineers receive, should possess a high level of technological and design culture. Also, due to the market conditions, they must have the required knowledge and practical skills for organization and management of the production of convenience goods. Students make original term and diploma projects in designing and producing new, competitive items for market and convenience services. Graduates of this specialty will be businessmen who are able to study market needs themselves, solve tasks of marketing and management, choose well-grounded strategies for firm development, and correctly develop business plans. They receive all the knowledge and skills to be professional businessmen.

Current specialists should know not only the technical side of projecting and producing, but also methods and remedies for managing production, and be able to organize advertising and marketing for their products. Taking this into account, the department provides the courses in management essentials, international marketing, psychology of transactions between buyer and seller, etc. This will allow graduates to successfully work in the conditions of the developing market economy.

\subsection{Specialty "Radio engineering "}

From the very beginning of existence, the VSTU provides a training of students in specialty Radioengineering (RE) along with another specialty "Design and Production of Electronic Devices" . These are the technical specialties the curricula of which difference each from other and involve a rational combination of technology courses. Thanks that are provided depth in a recognized technology discipline. For example, students in specialty of RE learn deepest such courses as electric circuits, electronic , digital systems, signals and systems, electromagnetic fields and so on, while students in another specialty learn deepest modern engineering technology which is directly related to their future activities. Therefore the specialists of these specialties are responsible for different design stages required for creation of electronic equipment and systems. To create any new electronic system it's needed to have a scheme, which should be designed from the idea to completed prototype project. This is main task of engineers in the specialty of RE, who are the circuit designers. To produce any electronic system it's needed to work up a construction and technological process of it production.

3. ORGANIZATION AND OPPORTUNITIES OF THE R \& D ACTIVITIES OF THE STUDENTS IN THE FIELD OF LASER TECHNOLOGY AND SCIENCES. AND THE DIRECTIONS UNDER STUDY 


\title{
Structure and hierarchy of the laser sciences and technology facilities:
}

\author{
Vladimir State Technical University \\ Division of the International Laser Center of Moscow State University \\ Laser Technology Center of Vladimir Region \\ associated with \\ Laser Military Industrial National Laboratory \\ Federal Center of Conversion Programs \\ Laser Medicine Center \\ associated with \\ Medicine scientific /practical laboratory of Vladimir Region
}

\subsection{General description of the opportunities}

The lasers produced are provided with computer-assisted technological equipment intended for special laser material treatment process: welding, cutting, surface hardening in close conformity with customer demands. The students can participate in any University structures for training and acquiring of the practical experience of their future profession.

The University has some specialized divisions responsible for:

-design and production of laser techniques;

-laser optics and optic-mechanical units development and production;

-automation systems and auxiliary devices development and production;

-technological processes and equipment development

-laser chemistry and biology.

Some new directions in laser physics and techniques are being developed:

-laser medicine;

-laser measurements and laser environmental control;

-laser micro technology.

The investigations are conducted in the following directions:

-creation of industrial solid-state lasers (energy up to $4 \mathrm{~kJ}$ ) based on material with improved

parameters for application in different technological processes of metal treatment;

-development of laser micro technology processes including creation of experimental systems of thin films microelectronics elements fabrication by laser chemical deposition from gas phase direct driving and laser spraying;

-development of laser medical systems for different purposes(therapy, surgery, diagnostics) on

the basis of conducted investigations of laser radiation and biological tissues interaction;

-creation of laser measuring systems and laser spectrometers for industrial and environmental control

(measuring of parts dimensions during their treatment, gas impurities detection and their concentration measuring);

-development, industrial production and introduction of flexible industrial laser treatment systems

using $\mathrm{CO}_{2}$ laser radiation, including the high power lasers(power up to $45 \mathrm{~kW}$ and even more);

-development of new technological lasers processes such as stones', ceramics', quarts glass

cutting, surface treatment using alloying and addition materials, welding of different metals and materials with high reflection of $\mathrm{CO}_{2}$-laser radiation (using the experience in area of specialized laser technique and technology creation);

-creation of three-dimensional objects and master-forms by laser stereo-lithography technique (computer control photo polymerization technique and induced 3D-pattern in condensed matter). 


\subsection{Project list (standard devices which are included in the education process).}

Laser Medicine:

-laser medical devices for low intensity therapy (tumors, dermatology, cosmetology) based on $\mathrm{He}-\mathrm{Ne}$ and semiconductor lasers

-laser Nd/YAG system for surgery, endoscopy and therapy

-laser surgery system with $30 \mathrm{~W} \mathrm{CO} 2$ laser (for

ENT, GIN, dermatology etc.)

-laser $\left(\mathrm{Nd} / \mathrm{YAG}+\mathrm{CO}_{2}+\mathrm{Cu}\right)$ medical system

Lasers and Laser System for Industrial Measurements, Environmental Control and Scientific Researches:

-laser interferometers based on $\mathrm{He}-\mathrm{Ne}$ or semiconductor lasers

(stabilized, full automatic registration)

-laser aerosol analyzer (measured particles $D=0.3-8.0 \mu \mathrm{m}$, counting rate up to 10000

particles/sec)

-IR laser spectrometer $(2-4 \mu \mathrm{m})$ for local and distance(up to $100 \mathrm{~m}$ ) control of atmospheric impurities

-IR spectrofluorimeter for temperature and concentration measurements

-tunable laser spectrometer in visible and near IR for remote sensing

Laser Systems for Micro technology:

-laser system for three dimensional growth of polymer material objects (dimensions

$250 \times 250 \times 250 \mathrm{~mm}$, resolution $50 \mu \mathrm{m}$ based on $\mathrm{He}-\mathrm{Cd}$ or excimer laser)

-solid state laser system for 3D-pattern induction in condensed matter

Industrial $\mathrm{CO}_{2}$ Laser Machining Units, IR Optics:

-industrial $10 \mathrm{~kW} \mathrm{CO}$ laser for high speed cutting (up to $60 \mathrm{~m} / \mathrm{min}$.) of thick material, welding of 20-30 layers of thick materials)

-industrial $5 \mathrm{~kW} \mathrm{CO}$ laser (welding, cutting)

-computer controlled laser machining units based on industrial $\mathrm{CO}_{2}$ laser

-computer controlled laser machining units based on $1,5 \mathrm{~kW} \mathrm{CO} 2$ laser

-fast axial flow industrial $\mathrm{CO}_{2}$ laser(0,6-1,2 kW) with high quality of laser beam; for high precision cutting, marking, hole punching

-IR optical components for industrial $(1-10 \mathrm{~kW})$ lasers: mirrors, windows with high reflectivity coatings, anti reflection and protective coatings 30-100 mm (materials: $\mathrm{Cu}, \mathrm{Ge}, \mathrm{ZnSe}, \mathrm{KCL}$ etc.)

3.3 New Proposals (Unique kind machines and original approaches) under developing for the student $R \& D$ activities

\subsubsection{Laser test facilities associated with external companies}

High power mobile autonomous industrial laser-robot (above $10 \mathrm{~kW}$ )

Laser Material Processing System:

- $\mathrm{CO}_{2}$ - Laser ( $45 \mathrm{~kW}$ )

- workstation

- transportation system (truck (trailer) - borne)

- autonomous voltage supply

- robotics equipment

- computer control and data storage 
Laser technology with wide-aperture solid state laser beams:

-High Energy Kilojoule-class Solid State Nd-glass Laser Array with Sum Energy about Megajoule

-Fast Growth of Wide-Aperture KDP-Family Crystals

-Large-aperture Q-switched Laser and Beam Control System

-Large- aperture Nonlinear Optical Harmonic Generation with High Efficiency

High accuracy selectable beam mode, quick adjustment and re-alignment industrial laser system under multi-lengthwave operation ( based on $\mathrm{Cu}, \mathrm{He}-\mathrm{Cd}$ and $\mathrm{YAG}$ : $\mathrm{Nd}^{\wedge} 3$ lasers ) with fiber optic delivery

Simultaneous high accuracy laser-monitoring of industrial processes, e.g. of welding, ("in-situ" measurement and in-process beam monitor ) based on a copper-laser

Super-high precision work station for using in the fiber optic, electronics and sensor industries, laserindustry and laser in medicine, tunneling microscopy

The super-high sensitivity tunnel-coupled fiber sensors of physical influences

Laser-induced gratings for application in laser optics

The laser computer-control photo polymerization system to produce the complicated geometric 3D-bulk details and objects for industry and medicine

The CO-laser ( 2,6 $\mu \mathrm{m})$ industrial complex

The short length-wave reliable gas industrial lasers

\subsubsection{Fundamental physics in laser and fiber optics at the university level}

A cw He-Ne laser $(0.633 \mu \mathrm{m})$ with extremely high coherence (both spatial and temporal) which has a super low (ultimate) noise level of laser radiation determined by spontaneous emission

Transformation and suppression of noise in laser pulses and beams by nonlinear interaction of light in a multichannel optical fiber (dual-core, spatially periodic etc.) under Bragg resonance condition (phase control all-optical scheme)

Formation of squeezed quantum light and quantum correlation in a fiber distributed feedback system

Quantum non-demolition measurements by multichannel optical fibers

Compression of laser pulses and beams in a nonlinear distributed optical system

Quantum optical solutions and chaotic regimes in nonlinear optical fibers with the energy transformation

Polarized squeezed quantum light and chaos in multichannel nonlinear optical system

The super high accuracy time-resolved correlation heterodyne spectroscopy for dynamic scattering of laser beams in a condensed matter

3D-structures and all-optical physical modeling in time and space of the instabilities and neural networks

3.3.3 Directions of current research with the student participation of different levels

- High power industrial $\mathrm{CO}_{2}$-laser. 
- Multipurpose flexible laser machining equipment for laser material processing.

- Fiber optics physics and technique.

- Laser medical treatment and diagnostic systems.

- Laser interferometric devices for different purposes.

- Super high sensitive laser measuring devices.

- Adaptive optical elements for laser beam and pulse control.

- Methods and equipment for the laser thin films deposition and laser induced gratings and their patterning for the planar optics and microelectronics applications.

- The super high accuracy heterodyne $\mathrm{CO}_{2}$-lidar.

\subsubsection{Current activities for the city services in a order to guarantee of employment among the students}

- Movable atmospheric environment monitoring station for remote sensing

The monitoring station is used for the determination of trace gases in the atmospheric environment and measurement of the average concentration along the path of sensing (including zones of power-houses, gas-mains and chemical industry, city districts and other enterprises).

Measurements are based on the laser IR absorption on the path between the station and retroreflector (mirror or topographic (trees, houses and so on) retroreflectors). The differential method is used to make accurate measurements. The detection limits of trace gases depending on the absorption cross section and absorption path length are equal to $10^{13} \ldots 10^{15} \mathrm{~cm}^{-3}$. Some detected gases and detection limits are corresponded to the standards of the Department of Ecology.

The mobile laboratory setup has been designed and constructed to check the measurement principles. The analysis of the reflected laser radiation allowed to evaluate the average methane concentration 1.5 $\mathrm{ppm}$ in the area between the setup and the retroreflector with sensitivity of $0.1 \mathrm{ppm}$.

- Time-resolved picosecond laser fluorescent spectrometer(for precision analysis in biology, chemistry, biophysics)

\section{CONCLUSION}

The basic conception and the main idea of the proposed approach to preparation of specialists in the field of the laser sciences and technology and to develop an optical education at Vladimir State Technical University, is based on the principle of unification of the teaching process, scientific activities and practical work to combine the compatibility, quality, high technologies and universality for future specialists in the field of both fundamental and applied branches.

All students receive a background in both fundamentals and applied disciplines through a set of courses taken typically in the sophomore or junior year. They can then choose which direction to follow in their fundamental and engineering concentration. Training of the engineers, able to create modern laser devices, requires greater efficiency and higher quality of curriculum, especially in laser technology education. As future engineers, students are needed to have an laser, electronics design and fabrication experience. A set of learning courses must be certainly in responding to industrial needs in the new technological world. Therefore, we offer to our students carefully planned curricula for two degree level (B.Sc. and engineer) - see Table 8. Objectives of these curricula are the following, among other things:

- to teach to identify problems and their solution;

- to teach to apply the theory in practice work;

- to teach to work both individually and in a group;

- to give fundamentals of systematic, creative and independent thinking.

The purpose of the curricula is to provide for a broad education preparing the student for imaginative and responsible activities in electronic and laser industry, and also in medicine.

Important to note that because the students at VSTU are the university level educated people, a knowledge of business could help them create cooperative relationships with high technology industry. These relationships can add relevance to the research and will influence the students attitude to succeed 
in the industrial workplace. Some funding agencies are more likely to support the research if they are doing it in the context of an industrial relationship.

In such an approach the organization of Regional Scientific-Technical Centers associated with the Technical University (as a Laser Engineering Center, a Laser Medicine Center, a Computer Technology Center, Geoinformation Center, etc.) is a very perspective thing and should be developed in large scales. And in fact, our activity and activity of Administration of the University is directed one's way at present. We have a support from both Federal and Local Administration Offices of Higher Education, Science and Technology.

\section{ACKNOWLEDGMENTS}

This research was partly supported by the International Science Foundation (The Soros Foundation) and the Russian Foundation of Fundamental Research 
6.APPENDIX

Curriculum Profile, Year 1

Specialty "Applied Mathematics (and Physics)"

TABLE 1

\begin{tabular}{|c|c|c|c|c|c|c|}
\hline \multirow{2}{*}{$\begin{array}{l}\mathrm{N} \\
\mathrm{O}\end{array}$} & \multirow{2}{*}{ NAME OF COURSE } & \multirow{2}{*}{ KIND OF TRAINING } & \multicolumn{2}{|c|}{ HOURS PER WEEK } & \multicolumn{2}{|c|}{ RESULT } \\
\hline & & & FALL & SPRING & FALL & SPRING \\
\hline 1 & Higher Mathematics & $\begin{array}{l}\text { Lecture, Lab, Practice, } \\
\text { Self-Study }\end{array}$ & 7 & 6 & exam & exam \\
\hline 2 & Physics & $\begin{array}{l}\text { Lecture, Lab, Practice, } \\
\text { Self-Study }\end{array}$ & 5 & 5 & exam & exam \\
\hline 3 & History & $\begin{array}{l}\text { Lecture, Practice, Self- } \\
\text { Study }\end{array}$ & 2 & 2 & credit & exam \\
\hline 4 & Foreign Language & Practice, Self-Study & 4 & 4 & credit & credit \\
\hline 5 & Physical Culture & Practice & 4 & 4 & credit & credit \\
\hline 6 & Computer Program & $\begin{array}{l}\text { Lecture, Lab, Self- } \\
\text { Study, Coursework }\end{array}$ & 4 & 3 & credit & exam \\
\hline 7 & Workshop & Practical Experience & - & 2 & - & credit \\
\hline
\end{tabular}

Curriculum Profile, Year 2

TABLE 2

\begin{tabular}{||l|l|l|l|l|l|l||}
\hline \multirow{2}{*}{$\begin{array}{l}\text { N } \\
\text { O }\end{array}$} & \multirow{2}{*}{ NAME OF COURSE } & \multirow{2}{*}{ KIND OF TRAINING } & \multicolumn{2}{l|}{ HOURS PER WEEK } & \multicolumn{2}{l|}{ RESULT } \\
\cline { 3 - 7 } & & & & & \\
\cline { 3 - 7 } & & & FALL & SPRING & FALL & SPRING \\
\hline 2 & Foreign language & Practice & 3 & - & exam & - \\
\hline 3 & Civilization & Lecture & 2 & 2 & credit & exam \\
\hline 4 & Hhysical Culture & Practice & 4 & 4 & credit & credit \\
\hline 5 & Physics & $\begin{array}{l}\text { Lecture, Practice, Lab, } \\
\text { Self-Study }\end{array}$ & 10 & 8 & credit & exam \\
\hline 6 & $\begin{array}{l}\text { Geometrical Modeling } \\
\text { and Computer Graphics }\end{array}$ & $\begin{array}{l}\text { Lecture, Practice, Lab, } \\
\text { Self-Study }\end{array}$ & 6 & 5 & exam & - \\
\hline 7 & Applied Mathematics & $\begin{array}{l}\text { Lecture, Lab, Self- } \\
\text { Study, Coursework }\end{array}$ & 4 & 4 & exam & - \\
\hline 8 & Computer Science & $\begin{array}{l}\text { Lecture, lab, Self-Study, } \\
\text { Course Project }\end{array}$ & 4 & 4 & - & - \\
\hline
\end{tabular}




\section{Curriculum Profile, Year 3}

\section{TABLE 3}

\begin{tabular}{|c|c|c|c|c|c|c|}
\hline \multirow{2}{*}{$\begin{array}{l}\mathbf{N} \\
\mathbf{O}\end{array}$} & \multirow{2}{*}{ NAME OF COURSE } & \multirow{2}{*}{ KIND OF TRAINING } & \multicolumn{2}{|c|}{ HOURS PER WEEK } & \multicolumn{2}{|c|}{ RESULT } \\
\hline & & & FALL & \begin{tabular}{|l|} 
SPRING \\
\end{tabular} & FALL & SPRING \\
\hline 1 & Philosophy & $\begin{array}{l}\text { Lecture, Practice, Self- } \\
\text { Study }\end{array}$ & 2 & 4 & credit & exam \\
\hline 2 & Physical Culture & Practice & 4 & 4 & credit & credit \\
\hline 3 & $\begin{array}{l}\text { History and Perspective } \\
\text { of Quantum Electronics }\end{array}$ & $\begin{array}{l}\text { Lecture, Practice, Self- } \\
\text { Study }\end{array}$ & 2 & - & - & credit \\
\hline 4 & $\begin{array}{l}\text { Ecology and Remote } \\
\text { Sensing }\end{array}$ & $\begin{array}{l}\text { Lecture, Practice, Self- } \\
\text { Study }\end{array}$ & 2 & - & credit & - \\
\hline 5 & $\begin{array}{l}\text { Management and } \\
\text { Marketing of Laser } \\
\text { Techniques }\end{array}$ & Lecture, Lab, Self-Study & 3 & - & credit & - \\
\hline 6 & $\begin{array}{l}\text { Theory of Probability } \\
\text { and Mathematical } \\
\text { Statistics }\end{array}$ & $\begin{array}{l}\text { Lecture, Lab, Self- } \\
\text { Study, Coursework }\end{array}$ & 4 & - & exam & - \\
\hline 7 & Theoretical Physics & Lecture, Lab, Self-Study & 4 & - & - & - \\
\hline 8 & Computer Science & $\begin{array}{l}\text { Lecture, Lab, Self- } \\
\text { Study, Coursework }\end{array}$ & 5 & - & credit & - \\
\hline 9 & Industrial Safety & Lecture, Lab, Self-Study & 3 & - & exam & - \\
\hline $\begin{array}{l}1 \\
0 \\
\end{array}$ & $\begin{array}{l}\text { Methods of } \\
\text { Mathematical Physics }\end{array}$ & $\begin{array}{l}\text { Lecture, Lab, Self- } \\
\text { Study, Course Project }\end{array}$ & - & 4 & - & exam \\
\hline $\begin{array}{l}1 \\
1 \\
\end{array}$ & $\begin{array}{l}\text { Principles of Quantum } \\
\text { Electronics }\end{array}$ & Lecture, Lab, Self-Study & - & 4 & - & exam \\
\hline $\begin{array}{l}1 \\
2 \\
\end{array}$ & Applied Mathematics & $\begin{array}{l}\text { Lecture, Lab, Self- } \\
\text { Study, Course Project }\end{array}$ & - & 3 & - & exam \\
\hline 1 & Theoretical Physics & Lecture, Lab, Self-Study & - & 4 & - & exam \\
\hline
\end{tabular}




\section{Curriculum Profile, Year 4 \\ TABLE 4}

\begin{tabular}{|c|c|c|c|c|c|c|}
\hline \multirow{2}{*}{$\begin{array}{l}\mathrm{N} \\
\mathrm{O}\end{array}$} & \multirow{2}{*}{ NAME OF COURSE } & \multirow{2}{*}{ KIND OF TRAINING } & \multicolumn{2}{|c|}{ HOURS PER WEEK } & \multicolumn{2}{|c|}{ RESULT } \\
\hline & & & FALL & $\begin{array}{l}\text { SPRING } \\
\end{array}$ & FALL & SPRING \\
\hline 1 & Elective (Liberal Arts) & $\begin{array}{l}\text { Lecture, Practice, Self- } \\
\text { Study }\end{array}$ & - & 4 & - & credit \\
\hline 2 & $\begin{array}{l}\text { Elective (Social } \\
\text { Science) }\end{array}$ & $\begin{array}{l}\text { Lecture, Practice, Self- } \\
\text { Study }\end{array}$ & 4 & - & exam & - \\
\hline 3 & $\begin{array}{l}\text { Psychology and } \\
\text { Pedagogy }\end{array}$ & \begin{tabular}{|l|} 
Lecture, Practice, Self- \\
Study
\end{tabular} & 4 & - & $\begin{array}{l}\text { credit, } \\
\text { exam }\end{array}$ & - \\
\hline 4 & Economics & $\begin{array}{l}\text { Lecture, Practice, Self- } \\
\text { Study, Coursework } \\
\end{array}$ & - & 4 & - & exam \\
\hline 5 & Computer Science & Lecture, Lab, Self-Study & 3 & - & credit & - \\
\hline 6 & $\begin{array}{l}\text { Principles of Quantum } \\
\text { Electronics }\end{array}$ & Lecture, Lab, Self-Study & 4 & - & exam & - \\
\hline 7 & $\begin{array}{l}\text { Testing of Laser } \\
\text { Equipment }\end{array}$ & \begin{tabular}{|l|} 
Lecture, Lab, Self- \\
Study, Coursework \\
\end{tabular} & - & 3 & - & credit \\
\hline 8 & $\begin{array}{l}\text { Introduction in Physics } \\
\text { of Nonlinear Processes }\end{array}$ & $\begin{array}{l}\text { Lecture, Lab, Practice, } \\
\text { Self-Study } \\
\end{array}$ & 3 & - & exam & - \\
\hline 9 & Digital-Optic Systems & \begin{tabular}{|l|} 
Lecture, Lab, Self- \\
Study, Course Project \\
\end{tabular} & 3 & - & credit & - \\
\hline $\begin{array}{l}1 \\
0\end{array}$ & $\begin{array}{l}\text { Systems of Laser } \\
\text { Technique }\end{array}$ & \begin{tabular}{|l|} 
Lecture, Lab, Self- \\
Study, Course Project \\
\end{tabular} & 3 & - & credit & \\
\hline $\begin{array}{l}1 \\
1 \\
\end{array}$ & $\begin{array}{l}\text { Materials of Quantum } \\
\text { Electronics }\end{array}$ & Lecture, Lab, Self-Study & 3 & - & exam & - \\
\hline \begin{tabular}{l|}
1 \\
2 \\
\end{tabular} & Computer Science & Lecture, Lab, Self-Study & - & 4 & - & exam \\
\hline \begin{tabular}{l|}
1 \\
3 \\
\end{tabular} & $\begin{array}{l}\text { Automation of Laser } \\
\text { Experiment }\end{array}$ & Lecture, Lab, Self-Study & - & 4 & - & exam \\
\hline $\begin{array}{l}1 \\
4 \\
\end{array}$ & $\begin{array}{l}\text { Diagnostic with Laser } \\
\text { Methods }\end{array}$ & Lecture, Lab, Self-Study & - & 3 & - & credit \\
\hline $\begin{array}{l}1 \\
5\end{array}$ & $\begin{array}{l}\text { Optical Information } \\
\text { Processing }\end{array}$ & Lecture, Lab, Self-Study & - & 4 & - & exam \\
\hline $\begin{array}{l}1 \\
6 \\
\end{array}$ & $\begin{array}{l}\text { Construction of } \\
\text { Optoelectronics } \\
\end{array}$ & Lecture, Lab, Self-Study & - & 2 & - & credit \\
\hline
\end{tabular}


Curriculum Profile, Year 5

TABLE 5

\begin{tabular}{|c|c|c|c|c|c|c|}
\hline \multirow{2}{*}{$\begin{array}{l}\mathrm{N} \\
\mathrm{O}\end{array}$} & \multirow{2}{*}{ NAME OF COURSE } & \multirow{2}{*}{ KIND OF TRAINING } & \multicolumn{2}{|c|}{ HOURS PER WEEK } & \multicolumn{2}{|c|}{ RESULT } \\
\hline & & & FALL & SPRING & FALL & SPRING \\
\hline 1 & $\begin{array}{l}\text { Management and } \\
\text { Marketing }\end{array}$ & $\begin{array}{l}\text { Lecture, Practice, Self- } \\
\text { Study }\end{array}$ & 12 & - & exam & - \\
\hline 2 & $\begin{array}{l}\text { Particularities of } \\
\text { Design of Different } \\
\text { Laser Equipment }\end{array}$ & Lecture, Self-Study & 6 & - & exam & - \\
\hline 3 & Lasers in Medicine & Lecture, Lab, Self-Study & 3 & - & credit & \\
\hline 4 & $\begin{array}{l}\text { Fundamental } \\
\text { Experiments with } \\
\text { Lasers }\end{array}$ & $\begin{array}{l}\text { Lecture, Lab, Self- } \\
\text { Study, Practice }\end{array}$ & 2 & - & exam & \\
\hline 5 & $\begin{array}{l}\text { Laser-induced } \\
\text { Photochemical } \\
\text { Processes } \\
\end{array}$ & Lecture, Lab, Self-Study & 3 & - & exam & \\
\hline 6 & $\begin{array}{l}\text { Projection and } \\
\text { Construction of the } \\
\text { Laser electronics } \\
\text { Equipment }\end{array}$ & Lecture, Lab, Self-Study & 2 & - & credit & - \\
\hline 7 & $\begin{array}{l}\text { Fuzzy Logic and } \\
\text { Neural Network }\end{array}$ & $\begin{array}{l}\text { Lecture, Lab, Practice, } \\
\text { Self-Study }\end{array}$ & 3 & - & credit & - \\
\hline
\end{tabular}

During of training students of the specialty "Applied Mathematics and Physics" have 4093 hours of classes, 6 course projects, 9 course works, 39 exams, 37 credits. Distribution of academic load is illustrated by Table 6.

\section{TABLE 6}

\begin{tabular}{|c|c|c|c|c|c|c|c|c|c|c|c|}
\hline \multirow{3}{*}{$\begin{array}{l}\mathrm{N} \\
\mathrm{O}\end{array}$} & \multirow{3}{*}{ TITLE } & \multicolumn{10}{|c|}{ YEARS, WEEKS } \\
\hline & & \multicolumn{2}{|c|}{1} & \multicolumn{2}{|c|}{2} & \multicolumn{2}{|c|}{3} & \multicolumn{2}{|c|}{4} & \multicolumn{2}{|r|}{5} \\
\hline & & 17 & 17 & 17 & \begin{tabular}{|l|}
17 \\
\end{tabular} & 17 & 17 & 17 & 17 & \begin{tabular}{|l|}
7 \\
\end{tabular} & \begin{tabular}{|l|l}
10 \\
\end{tabular} \\
\hline 1 & Academic Load & 28 & 28 & 28 & 26 & 28 & 28 & 25 & 24 & 24 & $28^{*}$ \\
\hline 2 & $\begin{array}{l}\text { Number of Course } \\
\text { Projects }\end{array}$ & - & - & 1 & 1. & 1 & 1 & 1 & 1 & - & - \\
\hline 3 & $\begin{array}{l}\text { Number of Course } \\
\text { Works }\end{array}$ & 3 & 3 & 4 & 7 & 6 & 4 & 6 & 7 & 6 & - \\
\hline 4 & Number of exams & 3 & 4 & 5 & 4 & 4 & 4 & 5 & 4 & 4 & - \\
\hline 5 & Number of credits & 5 & 4 & 4 & 5 & 4 & 4 & 4 & 2 & 2 & 1 \\
\hline
\end{tabular}

*Notice: Academic load of 5 th year is divided on the three short semesters (Table 7). 
TABLE 7

\begin{tabular}{|c|l|l|l|l||}
\hline $\begin{array}{c}\text { N } \\
\text { O }\end{array}$ & Name of Internship Program & $\begin{array}{c}\text { TIMETABLE } \\
\text { (Academic Year) }\end{array}$ & $\begin{array}{l}\text { Duration } \\
\text { (Weeks) }\end{array}$ & \multicolumn{1}{|c|}{ GOAL } \\
\hline 1 & Familiarization & 1 & 4 & $\begin{array}{l}\text { Familiarization with laser industry and to } \\
\text { get a work profession. }\end{array}$ \\
\hline 2 & Course Structure & after 4 & 4 & $\begin{array}{l}\text { To get to know about design and } \\
\text { fabrication of laser equipment. }\end{array}$ \\
\hline 3 & Pre-Diploma Project & 5 & $\begin{array}{l}\text { To carry out research in the frames of } \\
\text { the diploma project. }\end{array}$ \\
\hline
\end{tabular}

Structure of the multi-level education at Vladimir State Technical University TABLE 8

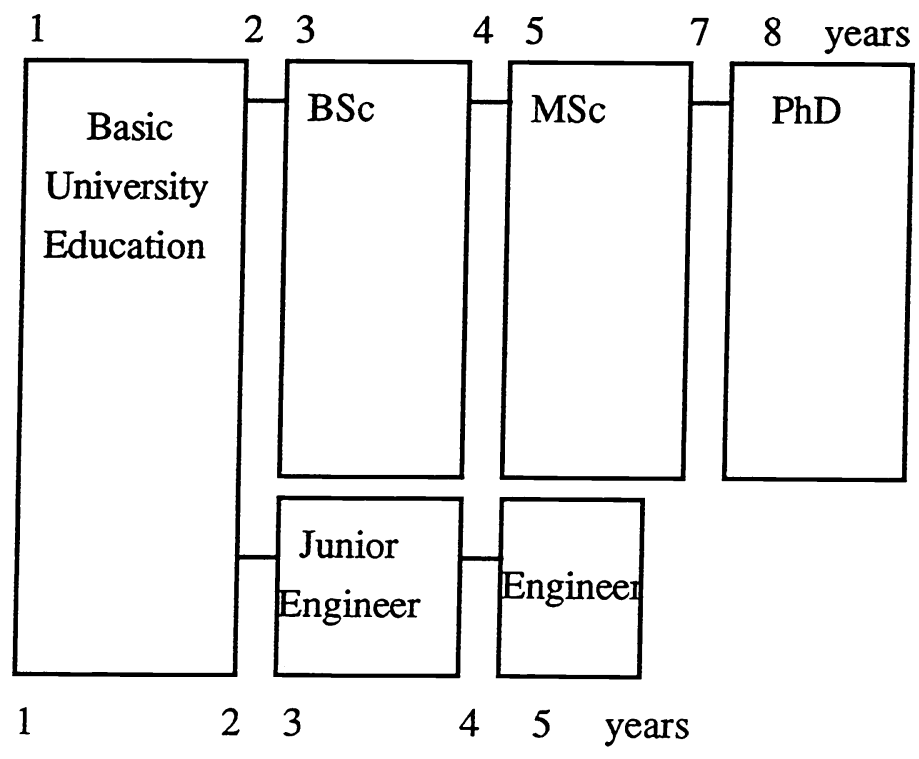

